\title{
DIGNITY
}

\section{Dignity: A Journal of Analysis of}

Exploitation and Violence

\section{What Telling of a Survivor's Story Will Finally Force a Remedy? Notes On A Silencing by Lacy Crawford and Is Rape A Crime? A Memoir, An Investigation, and a Manifesto by Michelle Bowdler}

Jody Raphael

DePaul University College of Law, USA, jraphae2@depaul.edu

Follow this and additional works at: https://digitalcommons.uri.edu/dignity

Part of the Criminal Law Commons, Criminal Procedure Commons, Evidence Commons, Family, Life Course, and Society Commons, Inequality and Stratification Commons, Jurisprudence Commons, Law and Gender Commons, Politics and Social Change Commons, Psychology Commons, Social Control, Law, Crime, and Deviance Commons, and the Social Work Commons

\section{Recommended Citation}

Raphael, Jody (2021) "What Telling of a Survivor's Story Will Finally Force a Remedy? Notes On A Silencing by Lacy Crawford and Is Rape A Crime? A Memoir, An Investigation, and a Manifesto by Michelle Bowdler," Dignity: A Journal of Analysis of Exploitation and Violence: Vol. 6: Iss. 2, Article 5. https://doi.org/10.23860/dignity.2021.06.02.05

This Book Review Essay is brought to you for free and open access by DigitalCommons@URI. It has been accepted for inclusion in Dignity: A Journal of Analysis of Exploitation and Violence by an authorized editor of DigitalCommons@URI. For more information, please contact digitalcommons-group@uri.edu. 


\section{What Telling of a Survivor's Story Will Finally Force a Remedy? Notes On A Silencing by Lacy Crawford and Is Rape A Crime? A Memoir, An Investigation, and a Manifesto by Michelle Bowdler}

\section{Keywords \\ Creative Commons License \\ (c) (i) (9)}

rape, victim, survivor, memoir, investigation, manifesto, institutions, school, law enforcement, rape kit

This work is licensed under a Creative Commons Attribution-Noncommercial-No Derivative Works 4.0 License.

\section{Acknowledgements}

Thanks to Editor-in-Chief Donna M. Hughes for suggesting the author review these two books, and for her helpful edits. 


\section{DIGNITY AJOURAL OF AMALYISIS}

Volume 6, Issue 2, Article 5, 2021

https://doi.org/10.23860/dignity.2021.06.02.05

BOOK REVIEW ESSAY

\section{WHAT TELLING OF A SURVIVOR'S STORY WILL FINALLY FORCE A REMEDY?}

NOTES ON A SILENCING BY LACY CRAWFORD

(LITTLE BROWN \& COMPANY, 2020)

IS RAPE A CRIME? A MEMOIR, AN INVESTIGATION, AND A MANIFESTO BY MICHELLE BOWDLER

(FLATIRON BOOKS, 2020)

\section{Jody Raphael}

DePaul University College of Law, USA

\section{KEYWORDS}

rape, victim, survivor, memoir, investigation, manifesto, institutions, school, law enforcement, rape kit

GOR YeARS NOW I HAVE BEEN SHARING SURIVOVR ACCOUNTS in presentations on acquaintance rape. My message is that rape will never be eliminated until law enforcement officers, prosecutors, judges, juries, educational institutions, and family members hold rapists accountable. At my very first talk, I was shocked by two immediate audience responses to my plea for accountability. First, one woman said that to eliminate rape, young girls need to stop drinking to excess and visiting bars in provocative clothing. Another opined that parents and schools need to educate "our ignorant boys" that they must get consent for sexual relations and not assault their dates. Every single time I spoke, these responses occurred, even from researchers at a national sociological conference. Clearly, my message was not getting through; audience members seemed unwilling to take a broader view, to consider how accountability for rape threatens male power, and all the measures societal institutions employ to support perpetrators, allowing rape to continue.

Now along comes novelist Lacy Crawford's powerful 2020 memoir, Notes on a Silencing, a book that forces readers to move beyond the superficial and simplistic platitudes with which my audience members regaled me. For within these 400 pages of Crawford's story is a description of every facet of the total patriar- 
chal system that produces and condones rape. This is a devastating, brutal account. Those able to get through the work will have a complete understanding of what it is going to take to end rape.

Because the book becomes a thriller, so as not to spoil the suspense, this review will not summarize Crawford's account in its totality. As a 15-year-old student at prestigious St. Paul's School in Andover, New Hampshire in 1990 (about 20 years after the school became co-ed), two student athletes Crawford knew lured her to their room under false pretenses. There, they physically forced her to perform oral sex on two of them, leading to ejaculation deep into her throat, along with fingers inserted in her vagina. The rapes were violent, but there was more violence in the aftermath of the assault. Crawford was blamed, shamed, ostracized, sexually harassed, and silenced by her female friends and classmates, the boys at the school, and later, even her parents, even though she never told anyone at the school what happened to her.

It started with the boys whispering a fallacious version of the events of that night that transformed Crawford from a victim to a willing participant. St. Paul's was happy to go along to preserve its reputation-a perfect storm that protected everyone except the young girl who was greatly harmed. The extraordinary cruelty of just about everyone at the school, and the alacrity with which everyone fell in line with the script created an unjust and immoral society, as described by Crawford:

It was the school's inhumanity I could not-cannot-overcome. Because now I was up against an institution that subsumes human beings and presents a slick wall of rhetoric and posture and ice where there should be thought and feeling. Thus is the world, this world, made ( $p$. 346).

Particularly difficult to stomach is the understandable ignorance of the young women at the school. Crawford describes a culture focused solely on heterosexual sex. The boys aggressively pursue it, and the girls go along, only seeing themselves as objects to be acted upon by the boys, who are at the center of the universe. Their lack of knowledge and confusion, depicted so brilliantly by Crawford, ensures their silence when faced with coercion and violence. Ultimately, they become "erased" (Crawford's term). Today, has the girls' knowledge and sense of efficacy increased at the school? There are reasons to believe they have not.

For in 2018 St. Paul's school signed a consent decree with the Attorney General of the state, in response to an investigation that found credible evidence of sexual abuse involving 20 former faculty member perpetrators over several decades, and school indifference to taking any action whatsoever. In lieu of charges, St. Paul's agreed to five years of government oversight and the appointment of a monitor to oversee the handling of sexual abuse claims at the school. Yet we learn from the press that in October 2020, after Crawford's book came out, the monitor quit his job, accusing campus officials of thwarting his efforts. The school, he said, discouraged investigations that could have legal impact, tried to limit his access to information, publicly berated him, and threatened to bring a civil lawsuit against him (Ramer, 2020).

Michelle Bowdler's memoir, Is Rape a Crime? A Memoir, an Investigation, and a Manifesto, concentrates on the U.S. legal system's lack of response to the crime 
of rape. In 1984 Bowdler was subjected to a violent home invasion, robbery, and multiple rapes. Despite the fact that similar crimes were occurring in her Boston neighborhood, her assailants went unidentified. Although Bowdler received excellent support from her roommates, friends, and family, her account demonstrates how such a brutal assault produces long-lasting, even life-long effects. She also comes to understand that the failure of accountability and lack of justice amount to another rape, preventing her recovery.

Twenty years later, when Bowdler decides to research just what the police department did to investigate her rape, her skimpy case file reveals that nothing was done. Even with the knowledge of serial rapists operating in her very neighborhood, evidence from the rape kit taken after the assault was never even submitted for DNA analysis. Embarrassed, the law enforcement official assures her this would never happen today. Given the backlog of rape kits still waiting for analysis and multiple contemporaneous accounts of rape survivors, Bowdler knows this statement is not true.

That nothing has changed is illustrated by a February 2021 article in the New York Times, in which women in Brooklyn, New York complained that despite the fact that 11 women had been assaulted at a local subway station, the police did not see fit to let the public know, nor designate the attacks as hate crimes that would have brought more investigative resources to bear. Indeed, the crime was solved and the perpetrator identified by one of the women, not the police (Southall, 2021).

Since Bowdler was raped by strangers, and it is thought that $80 \%$ of rapes are committed by someone the victim knows, at first glance her account might seem less important than Crawford's. However, as the book highlights the total indifference of law enforcement even to stranger rape, it illustrates the threat that sexual assault continues to present to police officers; their inaction wipes rape as a crime right off the books. Bowdler writes:

My manifesto is not a rallying cry for victims to act but a rebuke of current norms and a plea for change and accountability from law enforcement, whose job is to investigate and prosecute sexual assault, and from legislators, who speak too often about rape as if it is something other than a devastating crime of violence requiring a serious response. We can no longer allow the indifference toward sexual assault that leaves victims unable to rely on seeking justice for the crime they endured (p. 9).

Like Crawford's, Bowdler's book was brought out by a mainstream publisher. We can rejoice that these memoirs have found good homes, that the publishers understand the books' messages, and, importantly, have the resources and influence to aggressively publicize them. Reviewers have also recognized the power of these memoirs. For example, rave reviews of Crawford's book have appeared in The New York Times and The Washington Post. People Magazine listed it as one of the 10 best books of the year, Time Magazine cited it as one of 100 "must read" books of 2020, and an excerpt from the book appeared in Vanity Fair Magazine.

In promotional materials Little, Brown writes, "Notes on a Silencing wrestles with an essential question for our time. What telling of a survivor's story will finally force a remedy?" As heartfelt as this plea to listen to survivors is, the lesson of these books is that no amount of 
survivor testimony can dislodge rape so deeply embedded in our culture. Yes, we need survivor accounts. The silence of survivors gives us no chance to effectively fight rape.

But we also need action. One way is to demand accountability for rapists as well as for those who would deny rape, backed up with activities that go beyond street demonstrations, petitions, or op ed pieces. These could include recall and impeachment petitions, strikes, and boycotts.

Part of the problem is that women do not speak with one voice, with some even joining in the backlash against \#MeToo. Consider the 2018 U.S. Senate confirmation hearing for President Donald Trump's nominee Judge Brett Kavenaugh for a recent U.S. Supreme Court vacancy. In the hearing Kavenaugh faced an accusation of attempted rape when he was a high school student, but despite compelling and credible evidence, he was confirmed along party lines. Five Republican women voted to support him, including one who has related she was raped by a college boyfriend and later abused by her ex-husband (Knapp, Griffiths, \& McClure, 2018). Republican solidarity trumped women's solidarity. In a just world, every woman in the Senate should have been outraged by the nomination.

Without women's solidarity there is no chance. Women's failure to employ the power they have to speak with one voice dooms the campaign against rape. Rape survivors must come forward with their accounts, but we must support them with effective action. The lesson from these two important books is that women must ban together to demand specific change and accountability. What survivor's story will finally force a remedy is not the proper question. We cannot expect rape survivors to carry the burden of eliminating rape alone.

\section{ACKNOWLEDGMENTS}

Thanks to Editor-in-Chief Donna M. Hughes for suggesting the author review these two books, and for her helpful edits.

\section{AUTHOR BIOGRAPHY}

Jody Raphael is Senior Research Fellow (emerita), DePaul University College of Law, Chicago, Illinois. She has been researching in the areas of prostitution and human trafficking since 2001. She is the author of four books on violence against women with particular emphasis on denial. Her latest book is Rape Is Rape: How Denial, Distortions, and Victim Blaming Are Fueling a Hidden Acquaintance Rape Crisis (Chicago Review Press paperback).

\section{RECOMMENDED CITATION}

Raphael, Jody. (2021). What telling of a survivor's story will finally force a remedy? Notes on a silencing by Lacy Crawford and Is rape a crime? A memoir, an investigation, and a manifesto by Michelle Bowdler. Dignity: A Journal of Analysis of Exploitation and Violence. Vol. 6, Issue 2, Article 5. https://doi.org/10.23860/dignity.2021.06.02.05 Available at http://digitalcommons.uri.edu/dignity/vol6/iss2/5 


\section{REFERENCES}

Knapp, E., Griffiths, B., \& McClure, J. (2018, October 6). Kavenaugh confirmed: Here's how senators voted. Politico. Retrieved from politico.com/interactives/2018/brettkavanaugh-senate-confirmation-vote-count/

Ramer, H. (2020, October 19). Monitor for sex abuse claims at St. Paul's school quits, cites retaliation. CBS Boston. Retrieved from boston.com/news/localnews/2020/10/19/st-pauls-school-monitor-for-sex-abuse-claims-quits-citesretaliation/

Southall, A. (2001, Februrary 5. Woman after woman was attacked near a subway stop. Police kept quiet. The New York Times. Retrieved at nytimes.com/2021/02/04/myregion/mta-subway-attack.html/ 